\title{
Registration ten years on: A perspective from a social work educator
}

\section{Gavin Rennie}

Gavin Rennie is a Senior Lecturer in the Department of Social Practice at UNITEC and a Registered Social Worker.

Prior to registration coming into effect, social workers in this country were debating the pros and cons of its possible implementation. Seemingly most of this discussion took place within the New Zealand Association of Social Workers (NZASW) as it was then known. It is not the purpose of this paper to look at registration through the lens of the professional association, but it needs to be acknowledged that the Association provided the context where a lot of the debate took place.

In February 1994 the Association held a Special General Meeting which gave a mandate to set up a working party to consider proposals for the registration of social workers (Blagdon, Taylor, \& Keall 1994: 24). The working party was formed against a background of earlier discussions which had occurred with NZASW. Blagdon et al. posit that further questions need debate:

- Does NZASW want to pursue a statutory registration process?

- Who should be the registering body?

- What would the criteria for registration be?

At the outset I wish to state support for registration. I believe it to be in the interests of social workers themselves, and in the interest of the public as a means of protecting their safety by prescribing or providing mechanisms to ensure that social workers are competent to practise and accountable for how they practise (Orme \& Rennie 2006: 337).

This paper, through the use of experience and observation, explores the way social work registration has been implemented and developed in the last 10 years. The argument will be developed that this process has not been inclusive, and has not responded to the critique of academics and practitioners. Furthermore, it will be argued that the Board has gone beyond its mandate through its involvement in raising the bar in terms of registrable qualifications. This included moving from diploma to degree and latterly increasing the length of degrees from three to four years.

In 1996 the author became the Chair of the Aotearoa New Zealand Association of Social Work Educators (ANZASWE). ANZASWE at this stage represented seven polytechnics, three universities and the Auckland College of Education, all of whom were offering professional social work qualifications.

When the SWRB called for nominations, the author was one of those nominated by ANZASWE, and subsequently made the short list. As part of the interview process the importance of registration being compulsory was raised as was the issue of the Board being 
self-funding. Both the notion of 'choice' and 'user pays' (in relation to registration) were reflective of the growing neo-liberal agenda with its increasing commercialisation imperative and individualisation, and these issues were articulated as such. I guessed before leaving the room I would not be appointed. I was correct.

Critique is an essential part of social work discourse, and the input of communities of practice into the development of systems of power is an accepted part of this process. Since decisions were made to introduce registration critique has been proffered. There is little evidence, however, that these voices have been heard. This needs redress. This absence of response has been evident at a number of levels.

It will be argued that Government has not listened to the Board in relation to their recommendations as a result of the reviews in 2007 and 2012. The Board itself did take some action after the 2007 review and addressed issues around the competency process and did make some reduction in fees.

In the March/June 1997 edition of Social Work Review, Howard Randal, then a lecturer in the Department of Community and Family Studies at the University of Otago, raised issues about professionalisation. In doing so he drew on a paper he had given at an NZASW conference the previous year, which had linked regulation/ registration and professionalisation (Randal 1997). He concludes;

At this point there is little doubt that the Association should be a key player, if not, have a significant say, in any move toward the registration of social workers given its strong membership base, the substance of its previous debate around the issue of registration and credibility of the self-regulatory systems it has put in place (Randal 199: 19).

And later he opines:

Service delivery has been captured by new managerialism which means that control and management is less likely to be in the hands of professionals and more likely to be in the hands of managers who are driven by a need to create a market-driven enterprise to counter the retrenchment faced in resources and services (Randal 1997: 19).

It is against this background that in 2000 a consultation was initiated in response to a ministerial statement concerning the need to 'protect the safety of the members of the public'. (Maharey cited in Orme \& Rennie 2006). Registration, it was asserted, would improve the quality of social work services. Fitness and competence to practise are key pre-requisites to registration. Registered social workers will be made accountable for their practice through a new complaints and disciplinary process (Orme \& Rennie 2006: 336).

As a component of a consultation process, ANZASWE presented a submission to The Social Services Select Committee on the Social Workers Registration Bill. It was noted in the introduction to the submission that the Association was a member of the International Association of Schools of Social Work (IASSW).

To summarise this submission, the intent of the Bill was supported, which was to establish a regulatory framework for the registration of social workers. The Association also recognised that registration was a formal mechanism that would ensure that social workers 
'practice is competent, and thus offer extra protection to clients. (ANZASWE 2001: np). The ANZASWE noted current disparities (that impacted on social wellbeing) and noted that policies were needed in order to address these.

This macro focus was congruent with the recently promulgated IASSW / IFSW definition of social work, which states:

The social work profession promotes social change, problem solving in human relationships and the empowerment and liberation of people to enhance well-being .... Principles of human rights and social justice are fundamental to social work (as cited in ANZASWE, 2001, n.p.)

The submission went on to critique certain components of the draft Bill. These included the fact that there was no reference to the Treaty of Waitangi, no reference to the professional body for social work (ANZASW) and no reference to social work ethics.

Social work qualifications are awarded by educational institutions who are mandated to do this. The submission noted that the Board should not have authority within this domain, and a separation between education and registration needed to be maintained.

Recommendations from interested parties seemed to have little impact in producing amendments to the proposed legislation. None were incorporated into the Act and, as seen later in this paper, suggested amendments from the Board itself to Government have also met with no action

\section{Enacting the legislation, creating the board}

The Social Workers Registration Act became operative in 2003 following the establishment of the Social Work Registration Board (SWRB) as a Crown entity. Registration was non-compulsory.

The purpose of the Act was to establish and provide a regulatory framework for registration of all social workers in New Zealand based on an individual's competence and fitness to practise. Since its inception the Act has been reviewed, in 2007 and again in 2012. Within this process there had been some consultation.

Since its inception the SWRB became the designated body to ensure that competence was evidenced and maintained, and to provide sanctions and supports to the profession. Both the legal structure and the regulatory body would hold the mandate for providing the opportunity for registration within all the sectors where social workers are employed, both statutory and non-statutory (including those in private practice).

The original Board comprised 10 people, 6 of whom were required to be social work qualified and therefore eligible for registration. The Chair was to be elected from amongst the members. The appointment of the Board was made by the Minister of Social Welfare in November 2003. Educators and the profession were asked to provide names for consideration, the final decision remained however with the Minister.

The SWRB describes itself as, '... a crown entity with accountability to the New Zealand public and the Government, gives the public an independent voice in their interaction with social workers' (SWRB 2012: 2). 
This could seem to be both naïve and generative of the question: how can a body which is appointed by the Minister be considered as giving the public an independent voice?

Van Heughten (2011) has correctly identified there is an '... inescapability of the fact that social workers must always remain potentially willing to be critical of their employing organisations or state mandated roles' (van Heughten 2011: 186). I am left wondering if this level of critique is possible under these conditions and within this context.

\section{Voluntary or mandatory?}

The issue of voluntary or mandatory registration has been a conversation that preceded enactment of the legislation and the subsequent establishment of the SWRB.

The author, in the context of ANZASWE, was party to a number of meetings where registration was an agenda item. Paramount in arguing for registration was the need to protect social work clients and to ensure the accountability of social workers.

As part of its process, ANZASWE met yearly with senior management from the then Department of Social Welfare. The department had struggled with the commitment they had made to ensure that their social work staff obtained social work qualifications. A number of schools of social work made provision for block and part-time courses to assist partially qualified practitioners to complete their qualifications. Completed qualifications were less than expected. This and the percentage of employees with social work qualifications seems to have influenced the Department's attitude towards registration being compulsory. ${ }^{1}$

Latterly the Board produced a discussion document on mandatory registration (2010). This document was sent to a wide range of stakeholders with the invitation to respond. These included the public (especially social work services), social workers and employers of social workers across the state sector, private sector and non-government organisations, consumer organisations, social work representative bodies and umbrella organisations (within the NGO sector).

The response to this was that $95 \%$ were in favour of mandatory registration. Reasons were diverse and divergent, numerous and cogent. ${ }^{2}$ This recommendation was communicated to Government but to date there has been no change.

It is not unreasonable, I would suggest, to assume that the current political climate is implicated in the reluctance to make these changes (right of centre governments are usually against these sorts of processes being mandatory). Having said that it does take the bite out of a registration process. There would not seem to be other occupational groups in this country that have a registration process which at the same time remains voluntary.

When the act was brought into being in 2003 it was thought that it would enable the public to be protected and enhance the status of social work as a profession. This was part

1 Orme \& Rennie (200: 338) suggest that '... the decision not to make it [social work registration] compulsory related to the low levels of qualified workers in the Agencies.'

2 Unfortunately outside the scope of this paper to detail. 
of a wider initiative of the Ministry of Commerce for the regulation of occupations (Orme \& Rennie 2006).

As previously argued:

The key determinant of the need of regulation was whether an occupational group is capable of irreversible harm to the public and that statutory regulation was the only means to ensure adequate standards and procedures were in place to provide protection for consumers and the public (Orme \& Rennie 2006: 336).

It seems improbable that these laudable aims can be ensured if registration is not mandatory. An argument can be made that the title 'Registered Social Worker' gives some protection, but it can also be argued that consumers are not necessarily going to make a distinction between registered and unregistered practitioners.

The SWRB has made the case for registration to be mandatory, with overwhelming evidence of support. The power to make this change sits with Government.

\section{Raising the bar: Two, three, or four years?}

The advent of registration generated discussion around which qualifications rendered applicants eligible for registration. The country had moved quickly from small numbers of qualified social workers to an increasingly qualified workforce, most of whom had twoyear diplomas.

The earliest social work qualifications in New Zealand, offered at Victoria University from 1950 onwards, were predicated on the English model of three plus two. An undergraduate degree was assumed and then on top of that a two-year diploma in social work was offered. Later, other variations were offered.

Subsequent developments in the Auckland College of Education and in the 1990s in a variety of polytechnics, adopted a two-year diploma. Having said that, probably only a few students undertaking those courses of study had undergraduate degrees.

Massey University offered a four-year Bachelor of Social Work (BSW) which had generic papers in the first two years (mostly in the social sciences). Interviews were then conducted before students could move to the professional papers in years three and four.

Nash (1994) writing after many polytechnic programmes were in place, noted 'A variety of approaches is used in New Zealand to teach students how to be safe and competent social workers. Some have more academic content than others' (p. 52).

Proceeding to a discussion on the necessary inclusion of drawing on tangata whenua and the need for education around Treaty issues and Maori culture she continues:

The energy of tangata whenua that has given rise to greater awareness of Treaty issues - has gradually changed the course of social work practice, and therefore education and training for practice in Aotearoa/New Zealand (Nash 1994: 53). 
References to the Treaty are still notably absent from the legislation though there are course requirements set by the SWRB which do include such reference and there are teaching requirements in this area. An example of this is in Unitec's commitment to Te Noho Kotahitanga (the partnership).

While previously a diploma was the benchmark for registration, the SWRB in its wisdom raised the bar and called for a degree to be the new benchmark. A paper issued on behalf of the Board by Beddoe, Crichton-Hill and Hunt (2004) seemingly provided the impetus and support for this greater level of education.

This requirement caused ripples throughout the statutory, health and voluntary sectors. It was seen as moving too fast and without adequate processes of consultation. Capturing this sense of frustration, Pitt (2005: 41), asked 'Where is the open, on-going and rigorous debate about social work education? Is the registration board reflecting the social work community and most importantly, our clients? The degree stance indicates that they are not.'

Who controls power and knowledge has long been a debate in the social sciences. Foucault in particular has drawn attention to the inseparability of power and knowledge Foucault $(1972,1982)$. In other words, what is being asked is who has given the mandate to those who are making decisions, is it biased by their background and who defines truth or has the final word? In a postmodern world they are entirely appropriate questions.

Therefore the challenges made by Foucault in the late 1960s to the status and authority of doctors seem entirely relevant to this debate and the setting of a benchmark for education/ knowledge in our profession. Here it is important to remember:

Who is speaking? Who, among the totality of speaking individuals, is accorded the right to use this sort of language? And what is the status of the individuals who - alone - have the right, sanctioned by law or tradition...to proffer such as discourse? (Foucault as cited in Pitt 2005: 41).

In this case, the decisions to further raise the bar came from quarters seemingly with disregard for the effects on social work practice and education (and arguably the future 'face' of social work). There was no robust consultative process, and not surprisingly a resultant resistance rather than cooperation.

In 2012 the Board issued a further directive that four-year degrees would be mandatory from 2017. This proposal was greeted with concern by the polytechnic (ITP) sector. In response it made recommendations to the Board to the effect that this move was not needed and was based on some false premises and illogical inferences.

Amongst the concerns in a letter to the Board from chief executives representing the ITP sector (K. Giles, personal communication, Sept 2012) and subsequently sent to all ITP schools of social work the following points were made:

- There has been no feedback from industry regarding deficits or concerns around graduates from three-year programmes, and a four-year programme will increase debt levels for students, many of whom are Maori and Pacifica.

- Again there is no evidence that four years' undergraduate education is needed to demonstrate knowledge and skills for entry-level practice and further, a four-year programme 
could have significant impact on learners, and the diversity of the profession and public funding.

One can speculate on the process and the arguments that took place at the Board meeting which made the decision, but it seems likely that board members, who have worked in polytechnics, and those with Maori and Polynesian backgrounds, may surely have represented counter arguments to this proposal. Whatever transpired, the submission and the arguments were not acted upon. Social work schools are now, once more, scribing a new framework; this time a four-year degree.

Whilst there is some academic freedom in the development of courses, anxiety remains and there is increasing disease around the role and motivations of the Board.

An important consideration in the redesigning of courses is that they continue to conform to SWRB standards. ANZASW has previously cautioned that these standards could lead to a state-mandated curriculum for social work. This would be contrary to the academic freedom described in Section 161 of the Education Act 1989 and the spirit and purpose of the Social Workers Registration Act 2003.

Losing academic freedom could arguably lead to an increasingly technical approach to social work education and to social work practice.

Van Heugten (2011: 186) has recognised this and suggested that:

...[s]ocial work is not simply an application of social sciences nor of mere technical expertise. It should not be morally or intellectually subservient to organizations, the state or the law (albeit that attempts may be made to make it so) but it labours at the intersection of these systems.

\section{Conclusion}

The Board has been effective in promoting registration. There are approximately 6,000 social workers in New Zealand who are eligible for social work registration, and the 2011-12 annual report shows 3,522 Registered Social Workers.

Registration is important both in the interests of social workers themselves, and in the interest of the public as a means of protecting their safety by prescribing or providing mechanisms to ensure that social workers are competent to practise and accountable for how they practise (Orme \& Rennie 2006).

Registration is not, however, an apolitical activity. The shaping of the future sits in the current socio-political context. Co-option is always possible.

Throughout this paper it has been argued that social work educators have become passive recipients of various decrees from the Board There are many committed academics, rich in practice experience who would value the opportunity to contribute to good processes in the interests of their own profession. The values and theoretical basis of social practice are good foundations for development. They include a commitment to ongoing dialogue and collaborative processes. 
Acknowledgements. The author would like to acknowledge Craig Tunnicliffe, a colleague from the Deparment of Social Practice at Unitec for helpful and constructive feedback in the final drafting of this paper.

\section{References}

ANZASWE. (2001). Submission to the Social Services Select Committee on the Social Workers Registration Bill. ANZASWE: Auckland.

Beddoe, L., Crichton-Hill, Y. \& Hunt, S. (2004). Recognised qualifications in social work: Policy statement. Social Workers Registration Board.

Blagdon, J., Taylor, M. \& Keall, B. (1994). Social worker registration. Social Work Review 1994: 24-25.

Foucault, M. (1972). The archaeology of knowledge. Tavistock: London.

Foucault, M. (1982). The subject and power. In H. Dreyfus \& P. Rabinow (Eds.), Michel Foucault: Beyond structuralism and hermeneutics. University of Chicago Press: Chicago.

Nash, M. (1994). Social work education in Aotearoa/New Zealand. In Munford, R., \& Nash, M. (Eds). Social work in action. Dunmore Press Ltd: Palmerston North.

Orme, J., \& Rennie, G. (2006). The role of registration in ensuring ethical practice. International Social Work 49: $333-344$.

Pitt, L. (2005). Social work registration: Knowledge and power. Social Work Review 2005: 41-42.

Randal, H. (1997). Competent practice and its regulation: Debating the issues around the registration and professionalization of social work in New Zealand. Social Work Review March/June: 16-19.

Social Workers Registration Bill 2002 (No. 155-1).

Social Workers Registration Board. (SWRB). (2007). Review of the operation of the Social Workers Registration Act (2003). Retrieved July 2012 from: http: / / www.swrb.org.nz / files / Publications /SWRB_Act_Review_Report_July_07.pdf

Social Workers Registration Board. (SWRB). (2009a). Annual report 2008-2009. Retrieved July 2013 from: http:/ / swrb.org.nz / files / Publications /SWRB_AR0809.pdf.

Social Workers Registration Board. (SWRB). (2009b). The process for recognition/re-recognition of social work qualifications in New Zealand. Policy. Retrieved July 2013 from: http: / / www.swrb.org.nz / files / Policies / Recognition_1109.pdf.

Social Workers Registration Board. (SWRB). (n.d.). Recognising the social work profession (Brochure). Retrieved 2013 from: http: / / swrb.org.nz / files / NewApplicants / RegBro.pdf.

Social Workers Registration Board. (SWRB) (2012). Social Workers Registration Act (2003). Review Report October 2012.

Van Heughten, K., (2011). Registration and social work education: A golden opportunity or a Trojan horse. Journal of Social Work 11: 174-190. 